\title{
"Realismo" e subalternidade na narrativa brasileira contemporânea: o caso de Tropa de elite \\ Vinícius Gonçalves Carneiro ${ }^{1}$
}

Macho adulto branco sempre no comando

Caetano Veloso

\begin{abstract}
Não existe a primeira nem a última palavra, e não há limites para o contexto dialógico (este se estende ao passado sem limites e ao futuro sem limites)
\end{abstract}

Mikhail Bakhtin

Como o pobre, o oprimido, o afrodescendente ou todos aqueles desprovidos de uma identidade burocrática e simbolicamente institucionalizada podem ser ouvidos no cenário da produção cultural brasileira? Há outra proposta identitária que contradiga ou mesmo difira daquela de valores salvaguardados pelo sexismo, pela repressão e pela hierarquia das classes sociais? Que mecanismos representacionais impedem que tais vozes sejam ouvidas e configuram o silenciamento? A partir desses questionamentos, sob a esteira da teoria pós-colonial e após o sucesso de público e o debate relacionado ao filme Tropa de elite (2007)2, de José Padilha, almeja-se discutir o viés mediador e generalizador dos detentores do poder através da análise de algumas estratégias de ocultação de vozes e valores que se localizam fora do cinturão discursivo dominante.

Afinal, quem é o "brasileiro"? Que valores representa? O que e quem os seus valores calam? Para aproximar-se das respostas, o primeiro passo é compreender que qualquer identidade deve ser contextualizada socialmente, isto é, como a representação de uma raça, classe e gênero. Ao identificar Capitão Nascimento como pertencente a uma raça, classe e gênero detentora de poder, o movimento seguinte é estabelecer um olhar desconfiado e dialogicamente analítico quanto às afirmações, elucubrações e ações por ele produzidas.

\footnotetext{
${ }^{1}$ Doutorando em Teoria Literária na Pontifícia Universidade Católica do Rio Grande do Sul (PUCRS), Porto Alegre, Rio Grande do Sul, Brasil. E-mail: vinicius.gui@gmail.com

${ }^{2}$ Parte dos estudos sobre Tropa de elite busca no livro Elite da tropa, de 2006, o sentido "verdadeiro", a interpretação indubitável do filme. Todavia, a produção narrativa que causou a polêmica foi o filme, e não o livro. Logo, discutir o filme baseando-se no livro é afastar-se da questão central deste trabalho: a recepção de Tropa de elite pelo público brasileiro. Por isso, a análise será somente a partir da película.
} 
Vinícius Gonçalves Carneiro

No intento de evidenciar a notoriedade de uma diferença que não se limita a equações binárias como eu e o outro, o centro e a periferia, o especialista e o ignorante, o criminoso e o honesto, entende-se que toda identidade é dialógica e que carrega inexoravelmente uma alteridade, visível nos deslocamentos discursivos do sujeito enquanto representação de si mesmo e capaz de desconstruir quaisquer paisagens e monumentos identitários estanques, canonizados. À luz dessa trilha epistemológica, o foco de atenção recairá sobre os engenhos de opressão e as estratégias de silenciamento dos sujeitos emudecidos. A premissa básica é a de que as culturas são formadas por instituições culturais, representações, símbolos e imagens devidamente transformados em um discurso por meio de enunciados. No presente estudo, os sentidos e identidades advindos do discurso do Capitão serão pontilhados por contextualizações, comparações e digressões pertinentes a narrativas fílmicas, literárias e históricas, de acordo com alguns dos signos que gravitam em torno do filme, quais sejam: o êxito comercial, a recepção dicotomizada ${ }^{3}$, " "realismo", a violência, a representação do pobre e o carisma do personagem principal.

Toma-se como ponto de partida o romance de Machado de Assis Dom Casmurro, o qual trata do adultério, tema comum à época. É necessário ter em mente que a complexidade de leituras que legitimam o status de Machado é recente e resulta de um acúmulo bibliográfico. O texto de 1899 não foge dessa condição. Segundo Paulo Franchetti (2009), a crítica de Dom Casmurro divide-se em uma tríade de momentos. No século XIX, foi debatido se Capitu "traiu" ou "não traiu". Na década de 1930, colocou-se Bentinho no banco dos réus; Machado seria a testemunha de defesa que teria deixado pistas sobre o verdadeiro depoimento do protagonista, o que faria o leitor desconfiar da narrativa e mostrar-lhe-ia o caminho hermenêutico correto. Em um terceiro momento, verificou-se não só a insuficiência de intenções para enganar o leitor, mas que ele não é jurado nem destinatário da ação curativa. Bento e o leitor comum seriam réus, sendo este culpado por ser cúmplice daquele (do machismo, do elitismo, da dominação e da exploração de classe $)^{4}$.

Foi preciso quase cem anos de bibliografia crítica para que a obra de Machado fosse identificada como um conjunto de textos que tratou

\footnotetext{
${ }^{3}$ Vide "Tropa de elite é fascista?" (Bloch, 2007), "Capitão Nascimento bate no bonde do Foucault" (Azevedo, 2007) e "Tropa de elite: osso duro de roer" (Cuenca, 2007). Há ainda boas análises sobre a recepção do filme, como "Breve história de um fenômeno cultural" (Vieira, 2008), "Uma questão de ponto de vista: a recepção de Tropa de elite na imprensa" (Figueiredo, 2008) e "O (ab)uso da palavra fascismo: a recepção de Tropa de Elite" (Caldas, 2008).

${ }^{4} \mathrm{O}$ artigo de Franchetti vai além e problematiza a terceira fase de leituras sobre Machado.
} 
apuradamente das relações de poder, ascensão e subordinação na sociedade. $\mathrm{O}$ fato de a legitimação ${ }^{5}$ no sistema literário antecipar o acúmulo de leituras é um indício de como a imagem de um autor antecede e/ou dissocia-se de um entendimento profundo da sua escritura. A necessidade de perfilar o histórico dos olhares sobre Dom Casmurro, apartando-os do processo de consagração do autor, exemplifica como as interpretações efetivadas estão intrinsecamente ligadas ao contexto no qual são construídas.

\section{Realismo do cinema à literatura?}

Um mito sedimentado no imaginário brasileiro é o de que nossa produção cultural - sobretudo, a cinematográfica - seria obcecada por retratar o pobre, o miserável, o excluído. Contudo, conforme o estudo $O$ pobre em cena: representação no cinema brasileiro contemporâneo (Lins, 2009), menos de 30\% dos longas-metragens nacionais entre 1996 e 2006 possuem protagonistas pobres ${ }^{6}$. No âmbito cinematográfico, é provável que os motivos do mito estejam ligados às propostas temáticas e miméticas trazidas pelo Cinema Novo e pelo Cinema Marginal nas décadas de 1960 e 1970, o que foi reforçado nos últimos anos pelo sucesso de bilheteria de películas cujos personagens de destaque eram economicamente desfavorecidos ${ }^{7}$. Ainda de acordo com a pesquisa, as mulheres pobres são na sua maioria donas de casa, prostitutas ou empregadas domésticas, enquanto os homens pobres são na sua maioria bandidos, desocupados/desempregados, artistas, lavradores ou presidiários (Lins, 2009) - seres anônimos de características genéricas, "tipos" sociais úteis para retratar um estereótipo da periferia como local de criminalidade e bestialidade e cuja representação nas telas é com frequência definida como a "vida real" ou a "realidade" 8 .

\footnotetext{
${ }^{5}$ É possível que a legitimação tenha ocorrido por Machado ter sido o fundador da Academia Brasileira de Letras, por ser seu primeiro presidente, por ter tido suas crônicas amplamente difundidas em jornais e por nunca ter tido o nome envolvido em polêmicas com seus pares.

6 "Dos 211 filmes [entre 1996 e 2006] analisados, apenas 92 apresentam personagens pobres no seu enredo e dos 841 personagens considerados relevantes para a narrativa, apenas 229 são pobres - lembrando que aqui foram englobados pobres e miseráveis -, o que representa menos de $28 \%$ do total" (Lins, 2012, p. 88).

${ }^{7}$ Vide o caso de êxitos comerciais como O auto da Compadecida (2000), Cidade de Deus (2002), Lisbela e o prisioneiro (2003), Carandiru (2003) e Dois filhos de Francisco (2005), na lista dos dez filmes de maior público entre 1995 e 2006 (Lins, 2009, p. 89).

${ }^{8}$ Entre tantos outros, vide "Cinema brasileiro da Retomada: da pobreza à violência na tela" (Salvo, 2006) e "A realidade, só a realidade" (Carneiro, 2007). Sob os termos "vida real" e "realidade", respectivamente presentes nos artigos, subjaz ainda uma ideia de representação realista do mundo do fim do século XIX.
} 
A ambição de, por meio de tipos sociais, dar conta de dada "realidade" não é nova na representação artística nacional - muito menos na sua crítica. Machado de Assis, por exemplo, em uma das raras vezes em que foi polêmico, direcionou o seu veneno a um interlocutor específico, Eça de Queiroz, e a um tema em especial, o Real-Naturalismo. Considerado extremamente moralizante e ingenuamente pretensioso, o movimento estético com veleidades políticas e sociais, inspirado em Proudhon e radicalizado pela corrente naturalista, foi apontado pelo autor de Quincas Borba em "Eça de Queirós: O Primo Basílio":

O Sr. Eça de Queirós não quer ser realista mitigado, mas intenso e completo; e daí vem que o tom carregado das tintas, que nos assusta, para ele é simplesmente o tom próprio. Dado, porém, que a doutrina do Sr. Eça de Queirós fosse verdadeira, ainda assim cumpria não acumular tanto as cores, nem acentuar tanto as linhas [...]. Se tal suceder, o Realismo na nossa língua será estrangulado no berço; e a arte pura, apropriando-se do que ele contiver aproveitável (porque o há, quando se não despenha no excessivo, no tedioso, no obsceno, e até no ridículo), a arte pura, digo eu, voltará a beber aquelas águas sadias, d'O Monge de Cister, d'O Arco de Sant'Ana e d'O Guarani. (Assis, 1994).

$\mathrm{O}$ "tom carregado das tintas", o "acumular tanto as cores" e o "acentuar tanto as linhas" fazem referência a uma escrita preocupada em apresentar catarros e cuspes, detalhe por detalhe. As cenas descritas buscam uma verdade, a representação fidedigna do podre, do burguês e do corrupto, expondo as mazelas da sociedade portuguesa. Machado finda por assinalar o inútil de uma objetividade real-naturalista, problematização também perceptível no Impressionismo, no Expressionismo, no Surrealismo e no Cubismo, entre outros movimentos da passagem do século XIX ao XX.

No cinema, com o desenvolvimento dos efeitos especiais (sobretudo com a computação gráfica a partir dos anos 1980), a produção hollywoodiana passou a caracterizar-se, conforme conceito de Jean Baudrillard, por uma estética da hiper-realidade, a qual pressupõe a existência de apenas uma dissimulação de sentido, um simulacro, "um real sem origem nem realidade" (Baudrillard, 1991, p. 8). Nos blockbusters, as imagens são pormenorizadamente trabalhadas: a complexidade dos corpos em combate, dos robôs em movimento, dos tiros, dos choques entre carros; as miudezas em câmera lenta da bala do revolver cruzando o ar, da cabeça explodindo, da mão decepada. Trata-se de uma representação da realidade que extrapola as capacidades perceptivas do olho humano e cujo intento é prender a atenção de quem assiste por meio de uma enxurrada inassimilável de 
informações visuais e sonoras. Exemplos são películas mais famosas por uma ou outra sequência do que por seus enredos, como $O$ resgate do soldado Ryan, de 1998, de Steven Spielberg, Transformer, de 2007, de Michael Bay, e Além da vida, de 2010, de Clint Eastwood. O público tem sede de ver o "real" na tela (mais real do que a própria realidade), e senti-lo fisicamente em vertigens, sustos e arrepios. De acordo com Paul Virilio, isso seria a radicalização de um processo originado nos primórdios da sétima arte, quando "imediatamente surge uma indústria de massa que processa diretamente o realismo do mundo através da aceleração cinemática, um cinema fundado no desarranjo psicotrópico e na perturbação cronológica" (Virilio, 1998, p. 50).

Mesmo sob a ascendência estética e mercadológica hollywoodiana, a aproximação entre representação realista e cinema brasileiro possui outras implicações. Trajetórias como as de boa parte dos personagens em Amarelo manga (2003), de Cláudio Assis, de Zé Galinha em Cidade de Deus (2002), de Fernando Meirelles, e de Máiquel em O homem do ano (2003), de José Henrique Fonseca, mostram seres com destinos traçados por um universo corrupto. No momento em que se identificam ares de um determinismo do meio, no qual homens potencialmente honestos transformamse em criminosos e/ ou depravados, percebe-se como o Real-Naturalismo criticado por Machado foi atualizado. No entanto, tal leitura da representação artística nacional não é inédita. Flora Süssekind, em Tal Brasil, qual romance?, faz um histórico do Realismo tupiniquim, dos princípios filosóficos e da prosa naturalista (de tipo clínico), passando pelo Romance de 30 (de ciclos) até chegar à prosa da década de 1970 (e suas particularidades): Já notas, prefácios e avisos de que costumam estar repletos os romances-reportagens o leitor aprende que o significado do que lê está fora do romance e deve ser procurado nas páginas de jornal. O romance apenas complementa o que já se sabe sobre a notícia (Süssekind, 1984, p. 175).

A prosa denominada romance-reportagem buscaria ser um band-aid catártico contra o corte lancinante causado pelo golpe militar de 1964 e agravado pelo AI-5 (Süssekind, 1984, p. 173-174). Melhor do que os três naturalismos ou a depreciação do romance-reportagem, cujas fragilidades conceituais advêm de análises calcadas em juízos de valor ${ }^{9}$, o que fica do texto de Süssekind é o esforço epistemológico precipitado em identificar

${ }^{9}$ Para mais informações, ver “Depois do pós-tudo” (Wolff, 2012). 
na prosa brasileira uma tradição real-naturalista ${ }^{10}$ - diagnóstico equivocadamente repetido em relação ao cinema ${ }^{11}$.

Em Tropa de elite, verifica-se, sim, o registro hiper-real do qual fala Baudrillard para expor a trajetória de um homem em busca de um objetivo, que terá de superar adversidades e derrotar vilões ${ }^{12}$. Qual o motivo, então, do rebuliço por uma história de mocinho e bandido, aparentemente tão hiper-real como qualquer blockbuster e cuja "estética da pobreza" seria típica da filmografia nacional? A resposta passa pelo dialogismo do filme, com enfoque nos relatos dos eventos enunciados pelo protagonista.

\section{Sob a voz em off}

A utilização da voz em off na sétima arte serve, de forma genérica, para contornar problemas da narrativa, enxertando informações em ações que poderiam ter sido entrelaçadas por um roteiro mais bem elaborado. No momento em que esse verdadeiro Deus ex-machina se soma a outros elementos para construir uma mesma carga informativa, o resultado é a redundância ${ }^{13}$. Porém, há outras consequências quando se escolhe um narrador distante da cena. Conforme a construção do discurso, a focalização está ligada à categoria do modo em que se regula o que é dito (Reis e Lopes, 2002, p. 164). O receptor, por sua vez, apenas tem acesso ao que é contado pela focalização. O voice over seria, assim, uma espécie do que a teoria literária consagrou como narrador autodiegético (Reis e Lopes, 2002, p. 259), que comumente busca cativar o leitor, aproximá-lo da sua maneira de enxergar as coisas (limitada pelo horizonte narrativo) e convencê-lo dos seus princípios e ações. Bentinho é o caso típico.

No cinema, o espectador é captado pela história que transcorre na tela; como que levado a outro mundo, permanece inerte frente às imagens, sem que possa parar, voltar ou avançar. O visível já está organizado. Em Tropa de elite, tal organização é reiterada nos primeiros minutos da trama.

\footnotetext{
${ }^{10}$ Para comprovar tal afirmativa, um estudo pormenorizado de autores como José Louzeiro há de ser confeccionado. Para uma crítica do conceito romance-reportagem, ver "A mimeses como ficcionalização do real no romance-reportagem" (Schneider, 2012).

${ }^{11}$ Se há traços de uma representação real-naturalista em Cidade de Deus (2002), O homem do ano (2003) e Amarelo Manga (2003), não se percebe o mesmo em O auto da Compadecida (2000), Lisbela e o prisioneiro (2003), Carandiru (2003) e Dois filhos de Francisco (2005).

${ }^{12} \mathrm{O}$ filme segue a métrica página-minuto, na qual cada página do roteiro corresponde a um minuto de exibição do filme e cada conjunto de páginas, a determinadas funções narrativas, quais sejam: apresentação, ponto de virada I, confrontação, ponto de virada II e resolução (Field, 2006).

${ }^{13}$ Por exemplo, em uma cena haveria: a) a interpretação dos atores (expressões faciais, trajes, situações, etc.); b) a trilha sonora que ratifica o teor do diálogo/da encenação; e c) uma voz em off que explica a ação.
} 
Objetivando explicar a estratégia para deixar a sua função no Batalhão de Operações Policiais Especiais (Bope), o narrador prenuncia quando se darão os flashbacks - ou seja, as trajetórias de Neto e Matias. Trata-se de uma voz proléptica, que produz enunciados posteriores aos eventos, ratificando e justificando as decisões do Capitão. Tudo o que diz é uma explicação ao "outro" que acompanha as suas palavras, um mea-culpa em que se misturam "vergonha e exposição, verdade e mascaramento" (Stam, 2008, p. 257).

Segundo Mikhail Bakhtin, todo o signo, assim como o enunciado, é de natureza social: é a linguagem que determina a consciência, a atividade mental, e é a ideologia que determina a linguagem (1999, p. 46-47). Logo, "a fala está indissoluvelmente ligada às condições de comunicação, as quais, por sua vez, estão sempre ligadas às estruturas sociais" (Bakhtin, 1999 , p. 14). A palavra é a arena onde se confrontam os valores sociais contraditórios, sendo identificáveis os conflitos de classe no interior do sistema (Bakhtin, 1999, p. 14). Além de refletir as estruturas sociais, o signo ideológico refrata uma realidade que lhe é exterior, contaminando o discurso de alguém pelo do "outro" social. Em longas, como o dirigido por Padilha, em que uma voz em off posterior ao presente da diegese comenta as cenas que cruzam a tela, percebe-se uma construção discursiva porosa, que reflete e refrata o mundo, pois o protagonista não possui uma visão una, coerente, separada dos discursos que o circundam. Tentado abafar essas vozes, o narrador promove a convergência do olhar do espectador para si e estabelece a crença no que é contado ao sobrepor esclarecimentos sobre as suas atitudes à concretude das imagens. Daí se origina o quiproquó de considerar o filme fascista - e não apenas o comandante do Bope. Bakhtin auxilia a esclarecer a confusão entre autor e personagem:

Veremos que não se pode nem falar de concórdia propriamente teórica entre o autor e a personagem; aqui se trata de uma relação inteiramente distinta; neste caso, ignora-se em toda a parte a diversidade essencial de planos do conjunto da personagem e do autor, a própria forma da relação com o pensamento e até mesmo com o conjunto teórico da visão de mundo.

$[\ldots]$

O autor de uma obra só está presente no todo da obra, não se encontra em nenhum elemento destacado desse todo, e menos no conteúdo separado do todo. $\mathrm{O}$ autor se encontra naquele momento inseparável em que o conteúdo e a forma se fundem intimamente, e é na forma onde mais percebemos a sua presença. A crítica procura 
Vinícius Gonçalves Carneiro

busca-lo no conteúdo destacado do todo, que permite identificá-lo facilmente com o autor-homem de uma determinada época, que tem uma determinada biografia e uma determinada visão de mundo (Bakhtin, 2010, p. 399).

A afinidade entre quem faz a obra e o personagem construído não é de concordância, harmonia, equivalência ou igualdade. A obra compreende o personagem, mas é formada por mais elementos; o personagem é tão-só parte de algo mais complexo. O conteúdo, da mesma maneira, não deve ser separado do todo da obra nem associado à biografia ou à posição ideológica de quem a fez. Em Tropa de elite, houve uma confusão entre o que o Capitão diz com o que o filme quis dizer e, finalmente, com o que o diretor do filme, criador ${ }^{14}$ do conjunto de figuras dramáticas e de suas respectivas trajetórias, quis dizer.

Como bem assinala o teórico russo, um texto é um universo de discursos, de pontos de vista, de histórias, e nunca há uma acepção última, uma verdade; no entanto, o mal-entendido entre texto, autor e significado ganhou outra proporção pela empatia de parte do público com o discurso de Nascimento, "princípio do conteúdo-forma que sedimentou a relação do autor-contemplador com o objeto em sentido real e o personagem [...], a ideia do autor-estético" (Bakhtin, 2010, p. 10). O que faltou, desse modo, foi um movimento de exotopia, um olhar que vem de fora, essencial para que o sujeito seja inteiro, completo, pois somente com o olhar do "outro" é possível se ver como um eu, estando a palavra do sujeito inexoravelmente contaminada pelo olhar externo, que lhe dá sentido e acabamento (Bakhtin, 2010, p. 10-11). Para que houvesse uma melhor compreensão da narrativa, seria necessária a construção de uma leitura pendular entre empatia e exotopia, o que permitiria vislumbrar a polifonia do longa e analisar como nele se discute a sociedade brasileira.

Ambicionando desvelar essas vozes, enfoca-se a construção discursiva do chefe do Bope em paralelo com alguns signos que gravitam ao seu redor. Na cena introdutória, a voz em off define quem e como são aqueles que trabalham na Segurança Pública carioca: "Policial tem família, amigo. Policial também tem medo de morrer. É por isso que nessa cidade todo policial tem que escolher: ou se corrompe, ou se omite ou vai pra guerra" (Tropa, 2007). Mal iniciada a diegese, sabe-se que há dois lados, os "caveiras" e os corruptos, o Batalhão e os traficantes, os honestos e os desonestos.

\footnotetext{
${ }^{14}$ Definiu-se Padilha como o criador apenas com fins didáticos. Porém, sabe-se que o cinema é uma arte polifônica por excelência, pois envolve muitos "autores" (diretor, câmeras, roteiristas, atores etc.).
} 
Continuando na sequência de abertura, há dois elementos que não se podem desconsiderar: 1) o gesto do protagonista de apontar o dedo para os PMs e repetir “Não vai subir ninguém!"; 2) a apresentação: “Meu nome é Capitão Nascimento, eu chefiava a equipe Alfa do Bope. Eu já tava naquela guerra faz tempo e tava começando a ficar cansado" (Tropa, 2007). Constitui-se aqui um mundo de malvados e bonzinhos em que há um instaurador supremo da ordem (metonimizado pelo dedo em riste), cujo nome de identificação não é o de batismo, mas o da patente militar. Tomase ainda conhecimento do anseio do protagonista em livrar-se do posto, motivo de orgulho e angústia. Como acreditar em tudo que diz?

Típico dos "romancistas modernos desde Dostoiévski", o desafio de assistir a um filme com um narrador não confiável é "deslindar as inconsistências e neuroses do narrador, penetrando no véu com que os narradores encobrem seus vícios (ou até suas virtudes)" (Stam, 2008, p. 253). Em Tropa de elite, há um movimento na narração de provocar uma estabilização agressiva ${ }^{15}$, deixando o espectador em um estado de excessiva segurança em relação ao que é contado - mesmo que o personagem principal seja atormentado e pouco crível. Portanto, o longa não pode ser defendido ou atacado dependendo da empatia ou antipatia com o agente do Bope. O que interessa é vislumbrar como é retratado quem está a sua volta - a família, os companheiros de profissão, os usuários de drogas e os pobres da periferia.

Após a cena inicial da subida na favela, Nascimento retorna ao apartamento penumbroso, sem farda. Rosane, a esposa grávida, dorme. Durante o café da manhã apressado do marido, ela diz que não engravidaria se soubesse que ele continuaria na polícia. A voz em off retruca "A Guerra sempre cobra o seu preço. E quando o preço fica alto demais, é hora de pular fora [...]. Eu precisava de um substituto" (Tropa, 2007). Explicitase que o objetivo não é combater o crime ou salvar inocentes, nem matar bandidos, nem prender corruptos. Sua tarefa é encontrar um substituto. Sua justificativa, ser um pai de família, o que quer dizer: ter um nome de batismo (em vez do nome do posto), estar vivo para o nascimento do filho. A senha para essa vida é dar à luz uma cria na corporação, que ocuparia o seu lugar de rei despótico.

Há dois pretendentes, catalogados de acordo com a visão militarmente dicotômica do narrador: "O Neto era um cara impulsivo, que agia antes de pensar. Já o Matias pensava demais antes de agir" (Tropa, 2007). Universitário e leitor de Foucault, Matias desconhecia uma lição

${ }^{15} \mathrm{O}$ conceito original é desestabilização agressiva e refere-se ao narrador em Dostoievski (Stam, 2008, p. 254). 
fundamental: um policial honesto não pode frequentar uma faculdade, aspirar a uma vida comum. Sua importância é "maior", impondo-se sobre os direitos daqueles passíveis de serem subjugados. O voice over complementa: "Pra virar oficial do Bope, o sujeito tem que saber onde pisa. Matias tinha muito que aprender" (Tropa, 2007, grifo do autor). Definitivamente, a faculdade de direito não é local para ser instruído quanto às leis do Batalhão.

Para Bakhtin, assim como cada enunciado é algo individual (razão pela qual deve ser estudado), "por trás de todo texto está o sistema da linguagem. A esse sistema corresponde no texto tudo o que é repetido e reproduzido e tudo que pode ser repetido e reproduzido, tudo o que pode ser dado fora de tal contexto (o dado)" (Bakhtin, 2010, p. 309-310). Um exemplo é o signo do livro estudado por $05^{16}$, Vigiar e punir, que analisa o sistema prisional na Idade Moderna. Tal período marca a transição das punições corporais, exibidas em espaços públicos, para os presídios como os da atualidade, cujo ícone é o panóptico e cujas bestialidades são baseadas na vigília e no controle (Foucault, 2010). Esse signo reverbera na violência exercida pelo Bope, seja nas incursões à favela, seja nos treinamentos para ser um "caveira". A partir de Foucault (2010), conclui-se que as agressões da força policial são semelhantes às da Idade Média. Logo, quem estuda para ser um advogado, promotor ou juiz compreende as teorias do filósofo francês e defende os direitos humanos não pode trabalhar na segurança pública. Isso porque, para subir no morro, é preciso estar "superarmado e de farda preta ${ }^{17 ",}$, como explica o Capitão (Tropa, 2007), e não preocupado com a integridade física e psicológica do próximo.

A transformação de Matias é fundamental para visualizar a gênese, o nascimento ${ }^{18}$ de um oficial de operações especiais. O derradeiro estágio da mudança é perceptível pelo contraste de cores durante a marcha pela paz,

\footnotetext{
${ }^{16}$ No treinamento do Bope, cada aspirante recebe um número, pelo qual são nomeados na corporação. Neto é o "04” e Matias, o 05.

${ }^{17}$ Uniforme do Bope.

${ }^{18}$ Forçando um pouco, o paralelismo entre a gênese de um "caveira" e o nascimento do filho do Capitão reverbera no nome daquele que deveria ser o "herdeiro natural" no comando da equipe Alfa, Neto. Há aqui a sugestão da sucessão (advinda de uma filiação sanguínea) entre o chefe (um suposto avô) e o subordinado (o neto). Vide os traços físicos de "06" - de pele clara e cabelo escuro -, semelhantes aos de Nascimento, e o depoimento deste em conversa com a esposa - "Pô, tem um cara lá que é bom pra caramba. [...] Porra, pilhadão! Parece comigo naquela época lá em que eu fazia o curso" (Tropa, 2007, grifo do autor). Nesta linha de raciocínio, o assassinato de Neto fratura o plano do Capitão de tal modo que o novo sucessor, Matias, é necessariamente bastardo (logo, nem parecido fisicamente, pois afrodescendente, nem ideologicamente, pois estudante de direito) e nascido contra a vontade, a fórceps (vide a manipulação antiética realizada por Nascimento que redunda na execução do Baiano por Matias).
} 
ao final da trama. Matias, já metamorfoseado em 05, de calça e camiseta pretas, irrompe a multidão, toda de branco, que participava do protesto pacífico. O futuro homem forte da corporação, o qual palestrara sobre Foucault e os modos de vigilância e repressão do estado, surra o jovem considerado culpado pela perda de 06 . A voz em off abona: "Ninguém faz passeata quando morre policial. Protesto é pra morte de rico. Quando eu vejo passeata contra a violência, parceiro, eu tenho é vontade de sair metendo porrada" (Tropa, 2007). Dá-se acabamento e justificativa ao espancamento, regozijando aqueles simpáticos ao protagonista. Uma punição anacrônica, pertinente a um mundo anterior ao da Idade Moderna, que converte o pupilo em um "policial de verdade", isto é, dicotômico, reacionário, bárbaro, que vive para o trabalho e anula a sua vida social.

O tecido poroso do discurso, visível com um movimento tenso entre empatia e exotopia, é mais evidente na preparação à chegada do Papa ao Rio. Símbolo da paz, João Paulo II faria com que ocorresse uma "guerra" ainda maior nas favelas para que não houvesse "guerra". E para quê? A equação é simples: "O Papa precisava do Bope. O Bope precisava de mim. E eu precisava de um substituto" (Tropa, 2007). Não existem aspirações nobres, redenção ou reflexões sobre a função social de uma Segurança Pública que produz a morte - cujo símbolo da caveira "não é à toa", como confessa o narrador (Tropa, 2007). Tais contradições, mesmo oriundas de enunciados peremptórios, expõem feridas e deixam cicatrizes. Os superpoderes funcionam somente quando a "farda preta" e o "fuzil na mão" exercem um poder coercitivo. No momento em que é necessário o diálogo e o reconhecimento da alteridade, as mãos tremem, o corpo geme em calafrios. São sintomas psicossomáticos de uma crise interna, de uma voz que tenta organizar um universo caótico e brutal e se vê desarmada sem o poder de mandar e matar. O corpo incerto, titubeante, é a sequela física do dilema: ser o indivíduo do dedo em riste ou um pai de família? O problema, aliás, é percebido pelo protagonista: "Pra mim, estratégia só tem lógica quando missão tem sentido. A operação do Papa era uma burrice. Numa situação normal eu só ia ficar puto, mas meu filho ia nascer. Eu não podia dar bobeira. Eu não queria morrer à toa" (Tropa, 2007).

O seu trabalho consiste em encontrar um substituto, que trabalhará até se ver obrigado a escolher entre a família e a profissão. Caso a prioridade seja a família, o trabalho do substituto passará a ser encontrar um novo substituto.

A grande ilusão é achar que apenas aquela missão não tem sentido. 
Vinícius Gonçalves Carneiro

\section{O subalterno não pode falar}

Em Pode o subalterno falar?, Gayatri Spivak, a partir de uma releitura do debate entre Michel Foucault e Gilles Deleuze, versa sobre a impossibilidade de fala do subalterno, definindo-o como aquele que não participa do circuito do imperialismo cultural (pois na "sombra"), o que não lhe permite estabelecer o diálogo com o "outro" dono do poder. A mulher, devido à hegemonia de sociedades sexistas, seria duplamente subalterna, já que duas vezes mediada (pelas classes abastadas e pelo homem) (Spivak, 2010). A noção de uma fala intermediada é fundamental à compreensão da relação entre o chefe da equipe Alfa e os "subalternos", visto que tudo é filtrado pelo voice over.

No filme, o pobre é constantemente humilhado: apanha e só responde o que lhe é inquirido. Sua voz claudicante somente reverbera quando a mãe do fogueteiro morto pede o corpo do filho ao Capitão. Nada mais justo do que enterrar o ente e vivenciar os rituais fúnebres para começar a lidar com a perda. A voz em off acusa o golpe: "[T]raficante mata fogueteiro que dá mole, e no fundo eu sabia disso [...]. A mãe do fogueteiro me fez sentir remorso, e para um oficial do Bope esse é um sentimento muito perigoso" (Tropa, 2007). A dor da perda de um filho transpassa as classes sociais, atravessa os muros de convívio e de valores impostos pela sociedade e salvaguardados pelo Estado, permitindo uma troca de experiências entre uma mãe pobre, sem poder nem recursos, e um homem branco de classe média, comandante de um esquadrão policial de elite.

Esse compartilhamento é mais significativo caso se considere que o protagonista se colocou na posição de pai a partir da tragédia familiar de outrem. No entanto, o exercício de alteridade não é completo. Na cena anterior, humilhara um estudante, o qual era considerado responsável (como toda a classe média) pelas mortes na favela. E fazer um menino que trabalha para o tráfico dizer algo na frente de seus pares e depois o soltar, sabendo que morreria, não é causar uma morte? Afinal, quem é responsável pelas mortes na favela? Na conversa com a mãe do fogueteiro, a questão de Nascimento não é assumir a responsabilidade, pedir desculpas, consolá-la ou comprometer-se a evitar futuras perdas em casos semelhantes. A solução é fugir: "Eu percebi que Rosane estava certa. Já tinha passado da hora de colocar alguém no meu lugar" (Tropa, 2007). Consequentemente, a mediação que se sobrepõe ao depoimento da mãe deturpa suas palavras, seu lamento e sua reinvindicação, apagando o seu lugar de fala. 
Atento ao todo da construção discursiva encadeada pelo narrador, apreende-se que uma das chaves para examinar essas conclusões ilógicas está no comentário sobre o plano de Matias e Neto para obter peças para a oficina: "O sistema não trabalha para resolver os problemas da sociedade. O sistema trabalha para resolver os problemas do sistema" (Tropa, 2007). O que identifica como sendo um problema da PM é exatamente o seu comportamento: fala como se estivesse alheio ao sistema enquanto reproduz um comportamento sistêmico. A busca intempestiva e perturbada para encontrar o corpo do fogueteiro é uma missão dele para ele mesmo, para matar seus demônios, fazendo com que consiga trabalhar-viver até arranjar quem o substitua.

\section{O gesto que cala}

O gesto de apontar o dedo surge diversas vezes ao longo da diegese. O primeiro, na cena inicial, direciona-se aos PMs e é acompanhado pela ordem de que eles não subam o morro. O segundo, na ação em que o fogueteiro é solto: ao identificar um estudante, o protagonista estende-lhe o dedo e acusa-o de ter cometido o assassinato do traficante, esfregando na sequência o rosto do jovem no peito perfurado do cadáver. $O$ terceiro ocorre no treinamento, no momento em que se bate com o indicador na cara do candidato ao som da frase "Pede para sair!". O quarto é quando Neto faz a "molecagem" de entrar na favela "sem estratégia". O gesto, apesar de não ser tão relevante para o enunciado como a palavra, é dialógico, pois sempre se dirige a alguém e serve para dizer algo (Bakhtin, 1999, p. 52).

No caso de Tropa de elite, apontar o dedo, assim como dar um tapa, evidencia uma relação de poder, superioridade e opressão: quem aponta tem a força e o poder de submeter, xingar e torturar. Quem é apontado responde, curva-se e, inevitavelmente, sofre calado. Em todos os casos, o dedo em riste é um simulacro da arma de fogo, extensão natural do corpo legitimada pela verdadeira arma, fuzil ou revólver, explícita ou implicitamente presa no coldre ou na bandoleira. Por isso, o quinto e fatídico ato de apontar é indispensável para se pensar a trama, acontecendo após a morte de Neto (entendida naquela ocasião como a única chance para sair do comando da equipe Alfa). Ao retorna ao apartamento e ver que a esposa tenta amenizar a situação, o protagonista estende o indicador e diz:

Não abre a boca pra falar mais do meu trabalho nessa casa. Você não fala mais do meu trabalho nessa casa. Você tá entendendo? Quem manda nessa porra aqui sou eu e você não vai mais abrir a boca pra 
Vinícius Gonçalves Carneiro

falar do meu Batalhão nessa casa. Você tá entendendo? Você entendeu? Quem manda nessa porra aqui sou eu! (Tropa, 2007).

Confunde-se o público e o privado, os comandados e a família, ser chefe e ser marido. O discurso de oficial do Bope invade a casa, deflagrando uma guerra sem vencedores, uma luta que o Capitão não suspeitava perder. Ironicamente, a morte de 06 significava a impossibilidade de voltar à família, mas é a reação que tem com a execução de Neto que faz Rosane sair de casa. Outro personagem célebre que enseja livrar-se de uma responsabilidade administrativa e cujo comportamento contundente e maquiavélico provoca empatia, mascara a atrocidade de seus atos e o faz perder a família em nome do trabalho, é Michael Corleone, da trilogia O poderoso chefão, de Francis Ford Coppola (2010 [1972-1974-1990]). O sucessor de uma família mafiosa ítalo-americana age indiscriminada e impiedosamente (mata o cunhado e o irmão, bate na esposa, afasta os filhos de si, mente a todos) com a finalidade de legalizar os negócios da famiglia e mantê-la forte como empresa (mas não necessariamente unida). Não por acaso, Michael e Nascimento acabam as suas trajetórias solitários.

No caso de Tropa de elite, o poder do Capitão por ser adulto, macho e branco impõe-se sobre diferentes subalternidades: o subordinado, o jovem, a mulher, o pobre e o afrodescendente. Sua voz apresenta e representa a família, os companheiros do Batalhão, a classe média e, mormente, os moradores da favela, caracterizando uma postura recorrente no romance contemporâneo brasileiro, no qual "o silêncio dos marginalizados é coberto por vozes que se sobrepõem a eles, vozes que buscam falar em nome deles" (Dalcastagnè, 2002, p. 34). A ausência de espaço e direito à palavra, nesse sentido, é uma espécie de metáfora de como a produção ficcional tupiniquim (seja literária, seja fílmica) media o pobre e de como o público que frequenta as salas de cinema (classe média e alta) condicionou-se a submeter os menos abastados.

\section{Sob a égide da estratégia}

O assassinato do sucessor é um terrível golpe nos planos do protagonista; porém, nem tudo estava perdido: "A morte do Neto foi uma tragédia pro Matias. Eles eram amigos de infância. E eu percebi que podia usar aquele sentimento. E eu ainda tinha a minha missão para cumprir" (Tropa, 2007, grifo nosso). O seu objetivo, como já comentado, é sair da corporação, ou seja, do locus de quem sempre subjuga o próximo. O paradoxo é que, para abandonar a ocupação em que esse modus operandi é imprescindível, ele deve reproduzi-lo. Isso provoca a multiplicação de 
missões "sem sentido": zelar pela segurança do Papa, encontrar o corpo do fogueteiro, resgatar PMs e caçar o Baiano na favela para fazer com que Matias o matasse são todas ações ineficazes contra o tráfico de drogas. Nesta última, entretanto, o absurdo da ofensiva é óbvio para muitos dos oficiais, os quais desistem por considerá-la um descalabro.

A falta de pertinência das operações está ligada ao vazio do substantivo estratégia, enunciado ad nauseam na película. No treinamento, ao ser pronunciada em vários idiomas a "estudantes" cujo dever era "prestar atenção", a palavra perde a força significativa, sendo relevante pelo efeito de monotonia que a repetição proporciona. A seguir, passa a ser considerada pelo voice over como "uma arte". Portanto, o Bope, baseado em um termo que tanto pode não ter significado como designar uma atividade superior, refinada e bela, realiza suas missões sem sentido, dirigidas por alguém que não suporta mais o seu ofício. Não é à toa que o esvaziamento semântico do vocábulo corresponde ao de chefiar a equipe Alfa: trata-se de carregar a pedra de Sísifo até que outro o faça.

O valor dado à estratégia traz outra vez à mente a trajetória de Michael Corleone, para quem qualquer decisão é business. Esse racionalismo liberal radical (metaforizado na sua imagem sentado, terno alinhado, perna cruzada e mão no queixo) leva-o a morrer desamparado, sem filhos nem companheira, nostálgico do passado e de suas paixões (ao contrário do seu pai, Don Corleone, que faleceu brincando com o neto). Em Tropa de elite, a dedicação à estratégia, marca do lugar ideológico de seu discurso, desumaniza o comandante, que não identifica as consequências de suas ações. Vide o assassinato de Neto: a priori trágico (a perda de um colega de trabalho), o evento torna-se mais uma etapa para transferir a pedra de Sísifo (pois crucial para convencer 05 a dedicar-se de modo integral à corporação e, assim, sucedê-lo).

Contudo, tendo Rosane saído de casa, já não seria tarde demais para deixar a função que exercia? A valorização da estratégia, da racionalidade, da centralização das decisões e do poder da arma de fogo (ligada a duas guerras mundiais, inumeráveis genocídios, muitas das ditaduras do século $X X$ e alguns bilionários da indústria bélica) é mais uma vez retratada no cinema na riqueza de contradições que lhe é pertinente. No caso de Tropa de elite, os paradoxos do discurso de Nascimento e as vozes que dele emergem comprovam os contrassensos de uma sociedade entre o progresso e a barbárie, a hospitalidade e a hostilidade. As vozes envolvidas na gênese de 05 provêm do dilema social brasileiro, no qual os ricos são protegidos, os pobres são agredidos e a classe média é responsável pela educação dos abastados (visto que é de onde sai boa parte dos 
professores) e pela formação de repressores (visto que é de onde sai boa parte da elite da polícia civil e militar). Um ciclo vicioso que conserva a estrutura de desigualdade e produz soluções imediatistas e egoístas, como na confissão ao final do longa:

A minha missão não era mais garantir o sono do papa. Essa missão o Neto já tinha cumprido. O que eu precisava era voltar pra minha família e deixar um substituto digno no meu lugar. Pra fazer isso eu tinha primeiro que pegar o Baiano. O que eu estava fazendo não era certo. Não podia esculachar os moradores pra encontrar um bandido. Mas, naquela altura do campeonato, amigo, pra mim, estava valendo tudo (Tropa, 2007).

O tom afirmativo contagia a maioria dos espectadores. O restante destes repele o discurso do Capitão e o confunde com o filme, não se detendo nas incongruências dos enunciados reacionários e binaristas de alguém cujo cotidiano é gritar, torturar e matar. $\mathrm{O}$ convencimento não vem à toa. O voice over dá forma, sentido e acabamento à consciência do "outro"; é um excedente de visão posterior aos eventos contados e demarcador de duas tendências discursivas: uma enérgica, agressiva, opressora e tensa (a do protagonista no tempo da diegese), e outra mais calma, cativante, de frases de efeito, definitiva (a da voz em off, distante da ação).

Assim se dá a manipulação de uma história que não é a do combate contra os traficantes, os criminosos ou os malvados, mas a de como um homem utiliza-se do sistema para fugir do sistema. Não é a representação do real, mas o ponto de vista de um narrador suspeito, notório por incoerências e intersecções com outras vozes e realidades - por mais que tente calá-las. Diferentemente de alguns dos personagens de Cidade de Deus e $O$ homem do ano, nem Nascimento nem Matias são reféns do determinismo (05, por exemplo, é manipulado pelo superior, e ambos possuem destinos condicionados por escolhas ética e moralmente contestáveis).

Na trilogia O poderoso chefão, configura-se uma crítica ao racionalismo da lógica do capital, mas a empatia com o mafioso sisudo, de gestos precisos, cujas decisões são marcadas pela destreza e pela ousadia, acaba afastando uma interpretação exotópica, que problematize as implicações nefastas de um comportamento como o do filho de Don Corleone. O mesmo ocorreu com os leitores de Dom Casmurro, que, até a metade do século passado, decifravam o romance pelos olhos de Bentinho, não se interrogando de onde o narrador falava, com quem falava, para que falava, quando falava e, especialmente, em defesa de que valores falava. A recepção de Tropa de elite não difere muito, uma vez que, em geral, não se tomou conhecimento de que o comportamento do herói da história apenas o leva, 
no nível profissional, à violência gratuita, a operações sem sentido e a mortes desnecessárias (como a do traficante que ele interroga e depois executa, o colocando "na conta do Papa"); e, no nível pessoal, à destruição do casamento. Em outras palavras, interesses do protagonista, camuflados por um discurso em prol dos valores do sistema policial, ao fim e ao cabo, silenciam a mulher, o jovem, o subordinado e o pobre.

As contradições são dissimuladas pela ênfase com que as defende e pelo dualismo categórico que impõe como leitura de mundo. Essa força advém da existência de um destinatário, o espectador, posto que o personagem principal intenta legitimar (consciente ou inconscientemente) os crimes que comete frente ao "júri invisível" da opinião pública (Stam, 2008, p. 262).

Em que um membro do Bope assim pense, não há absurdo. Mas como a maioria da população aderiu às palavras do comandante? Em uma narrativa em que o protagonista agride verbalmente a própria esposa, bate em estudantes, manipula o subordinado e estigmatiza, humilha, surra e mata quem é da periferia, a plateia se limitou a santificar ou maldizer a película e o Capitão. O equívoco foi ignorar que o seu discurso incisivo é o "culpado" não somente por defender a tortura, mas também por evidenciar um posicionamento ratificador da desigualdade social e do respectivo silenciamento e/ou mediação nociva do subalterno.

Em uma sociedade hierarquizada e hierarquizante, que teve mais da metade de sua história maculada por regimes não democráticos e habituada a telejornais que noticiam a criminalidade como oriunda da pobreza, o brasileiro foi condicionado (ou condicionou-se) a não protestar contra a "autoridade"; pelo contrário, a admira. Essa admiração ajuda a compreender por que o discurso de dedo em riste, que se impõe pelo grito e só profere enunciados agressivos, foi e é aceito de maneira passiva. O real que a narrativa fílmica aborda é outro, distante da minúcia da hiper-realidade de cenas de tiroteio e perseguição (tão comuns em longas norte-americanos) ou do rótulo "realismo" (utilizado pela crítica nacional para tratar da ficção contemporânea desde Süssekind), mas próximo de produções culturais que, ao tematizarem assuntos em voga no seu tempo (no caso, a violência urbana), discutem a sociedade na qual foram produzidas nos seus meandros, como bem fizeram Flaubert e Machado no final do século XIX. O mesmo ocorre com Tropa de elite, que, ao descortinar um Brasil elitista, reacionário e repressor, confirma as constatações de Walter Benjamin (1986) sobre o barbarismo inerente à civilização e mina uma vez mais a ideia de que a arte humaniza ou de que inerente a ela estaria o progresso 
e o bem comum. No caso brasileiro, serão sempre os leitores ou culpados ou cúmplices de um país tal como o revelado pelo filme?

\section{Referências}

AMARELO Manga (2003). Direção: Cláudio Assis. Produção: Marcello Maia e Paulo Sacramento. São Paulo: Califórnia Filmes. 1 DVD (103 min).

ASSIS, Machado de (1994). Eça de Queirós: O Primo Basílio. In: Obra completa. Disponível em: <http://machado.mec.gov.br/images/stories/pdf/critica/ mact27.pdf>. Acesso em: 10 abr. 2012.

AZEVEDO, Reinaldo (2007). Capitão Nascimento bate no bonde do Foucault. Veja.com, São Paulo, 17 out. 2007. Disponível em: <http://veja.abril.com. br/171007/p_090.shtml>. Acesso em: 10 abr. 2012.

BAKHTIN, Mikhail (2010). Estética da criação verbal. São Paulo: Martins Fontes. (1999). Marxismo e filosofia da linguagem. São Paulo: Hucitec.

BAUDRILLARD, Jean (1991). Simulacros e simulação. Lisboa: Relógio d'Água.

BENJAMIN, Walter (1986). Documentos de cultura, documentos de barbárie. São Paulo: Cultrix.

BLOCH, Arnaldo (2007). 'Tropa' é fascista?. Arnaldo Blog, Rio de Janeiro, 25 set. 2007. Disponível em: <http://oglobo.globo.com/blogs/arnaldo/posts/2007/09/25/ tropa-fascista-artigo-que-motivou-texto-de-wagner-moura-74806.asp >. Acesso em: 10 jun. 2012.

CALDAS, Pedro (2008). O (ab)uso da palavra fascismo: a recepção de Tropa de Elite. Viso: Cadernos de Estética Aplicada, Rio de Janeiro, v. 2, n. 4. Disponível em: $<$ http://www.revistaviso.com.br/pdf/Viso_4_PedroCaldas.pdf $>$. Acesso em: 30 abr. 2012.

CARANDIRU (2003). Direção: Hector Babenco. Produção: Hector Babenco e Flávio R. Tambellini. São Paulo: Sony Pictures. 1 DVD (145 min).

CARNEIRO, Marcelo (2007). A realidade, só a realidade. Veja.com, São Paulo, 17 out. 2007. Disponível em: <http://veja.abril.com.br/171007/p_080.shtml>. Acesso em: 30 abr. 2012.

CIDADE de Deus (2002). Direção: Fernando Meirelles. Produção: Andrea Barata Ribeiro e Maurício Andrade Ramos. Rio de Janeiro: Imagem Filmes. 1 DVD (130 $\min )$.

CUENCA, João Paulo (2007). Tropa de elite: osso duro de roer. Blog de anotações, 25 set. Disponível em: <http://oglobo.globo.com/blogs/cuenca/posts/2007/09/25/ tropa-de-elite-osso-duro-de-roer-74711.asp>. Acesso em: 10 abr. 2012.

DALCASTAGNÈ, Regina (2002). Uma voz ao sol: representação e legitimidade na narrativa brasileira contemporânea. Estudos de Literatura Brasileira Contemporânea, Brasília, n. 20, p. 33-77.

DOIS FILHOS de Francisco (2005). Direção: Breno Silveira. Produção: Columbia TriStar Filmes e Conspiração Filmes. São Paulo: Sony Pictures. 1 DVD (132 min). FIELD, Syd (2006). Manual do roteiro: os fundamentos do texto cinematográfico. Rio de Janeiro: Objetiva.

FIGUEIREDO, Vera Lúcia Follain (2008). Uma questão de ponto de vista: a recepção de Tropa de elite na imprensa. In: ENCONTRO DA COMPÓS, 17., São Paulo, 
p. 1-13. Disponível em: <http://www.compos.org.br/data/biblioteca_334.pdf>. Acesso em: 10 abr. 2012.

FOUCAULT, Michel (2010). Vigiar e punir. São Paulo: Vozes.

FRANCHETTI, Paulo (2009). No banco dos réus: notas sobre a fortuna crítica recente de Dom Casmurro. Estudos Avançados, São Paulo, v. 23, n. 65, p. 289-298. Disponívelem:<http://www.scielo.br/scielo.php?script=sci_arttext\&pid=S010340142009000100019\&lng=en\&nrm=iso\&tlng=pt>. Acesso em: 10 abr. 2012.

GUIMARÃES, Hélio de Seixas (2008). O escritor que nos lê. Cadernos de Literatura Brasileira: Machado de Assis, São Paulo, n. 23-24, p. 273-292.

LINS, Paula Diniz (2009). O pobre em cena: representação no cinema brasileiro contemporâneo. Dissertação (Mestrado em Letras) - Faculdade de Letras, Universidade de Brasília, Brasília. Disponível em: <http://www.gelbc.com.br/ pdf_teses/Paula_Lins.pdf>. Acesso em: 10 abr. 2012.

LISBELA e o prisioneiro (2003). Direção: Guel Arraes. Produção: Paula Lavigne, Natasha Filmes e outros. São Paulo: Fox Film do Brasil. 1 DVD (106 min).

O AUTO da Compadecida (2000). Direção: Guel Arraes. Produção: Guel Arraes, Eduardo Figueira e outros. São Paulo: Sony Pictures. 1 DVD (104 min).

O HOMEM do ano (2003). Direção: José Henrique Fonseca. Produção: Conspiração Filmes, Estúdios Mega e outros. Rio de Janeiro: Warner. 1 DVD (113 min). O PODEROSO Chefão (2010). Direção: Francis Ford Coppola. Produção: Albert S. Ruddy. Los Angeles: Paramount Pictures. 4 DVDs (523 min).

REIS, Carlos; LOPES, Ana C. (2002). Dicionário de narratologia. Porto: Almendina. SALVO, Fernanda (2006). Cinema brasileiro da Retomada: da pobreza à violência na tela. Revista Espcom, Belo Horizonte, n. 1. Disponível em: <http:/ / www.fafich. ufmg.br/ espcom/revista/numero1/ArtigoFernandaSalvo.html>. Acesso em: 30 abr. 2012.

SCHNEIDER, Sabrina (2012). A mimeses como ficcionalização do real no romancereportagem. Revista Escrita, Rio de Janeiro, n. 14, p. 1-14. Disponível em: <http:/ / www.maxwell.lambda.ele.puc-rio.br/rev_escrita.php?strSecao=input0>. Acesso em: 10 set. 2012.

SPIVAK, Gayatri C. (2010). Pode o subalterno falar? Belo Horizonte: UFMG.

STAM, Robert (2008). A literatura através do cinema. Belo Horizonte: UFMG. SÜSSEKIND, Flora (1984). Tal Brasil, qual romance? Rio de Janeiro: Achiamé. TROPA de elite (2007). Direção: José Padilha. Produção: José Padilha e Marcos Prado. Rio de Janeiro: Universal Pictures Brasil. 1 DVD (114 min).

VIEIRA, Vladimir (2008). Breve história de um fenômeno cultural. Viso: Cadernos de Estética Aplicada, Rio de Janeiro, v 2, n. 4. Disponível em: <http:/ / www.revistaviso.com.br/pdf/Viso_4_VladimirVieira.pdf>. Acesso em: 10 abr. 2012. VIRILIO, Paul. (1998). Guerra e cinema. São Paulo: Brasiliense.

WOLFF, Jorge (2012). Depois do pós tudo. Fluxos literários, Florianópolis, 2012. Disponível em: <http://fluxosliterarios.blogspot.com.br/p/videos.html>. Acesso em: 10 set. 2012.

Recebido em maio de 2012.

Aprovado em outubro de 2012. 


\section{resumolabstract}

"Realismo" e subalternidade na narrativa brasileira contemporânea: o caso de Tropa de elite

Vinícius Gonçalves Carneiro

O artigo discute uma narrativa cinematográfica brasileira, Tropa de elite, de José Padilha, que tanta polêmica causou no país desde o seu lançamento. Para tentar compreender as forças de poder em jogo tanto na narrativa como na recepção do filme, busca-se contextualizar Tropa de elite em relação à cinematografia contemporânea hollywoodiana, a uma possível tradição real-naturalista nacional e à representação fílmica e literária brasileira do subalterno. Apenas após abordar tais relações, analisar-se-á dialogicamente como se dá a subordinação de personagens de diferentes classes sociais, gêneros e raças, constante e violentamente calados pelo protagonista do filme, o Capitão Nascimento.

Palavras-chave: cinema, literatura brasileira contemporânea, subalterno, dialogismo, Realismo, Tropa de elite.

"Realism" and subalternity in contemporary Brazilian narrative: Elite squad Vinícius Gonçalves Carneiro

This article discusses the polemic Brazilian movie Elite squad. To understand the power games behind the movie and its reception, it is important to contextualize Elite squad in the contemporary Hollywood production, in a hypothetical Brazilian Realism tradition and in the cinematographic and literary representation of the subaltern. After that, using Bakhtin's dialogism, it will be possible to analyze how some characters, such as the woman, the poor and subordinate, are oppressed by Captain Nascimento.

Keywords: cinema, contemporary Brazilian literature, subaltern, dialogism, Realism, Elite squad. 